\title{
Dietary Practices and Their Determinants Among Pregnant Women in Gedeo Zone, Southern Ethiopia: A Community-Based Cross-Sectional Study
}

This article was published in the following Dove Press journal:

Nutrition and Dietary Supplements

\author{
Mahlet Yalewdeg' \\ Mahlet Birhane ${ }^{2}$ \\ Yohannes Adissu ${ }^{3}$ \\ 'Department of Reproductive Health, \\ Gedeo Zone Health Office, College of \\ Health Science and Medicine, Dilla \\ University, Dilla, Ethiopia; ${ }^{2}$ Department \\ of Human Nutrition, College of Health \\ Science and Medicine, Dilla University, \\ Dilla, Ethiopia; ${ }^{3}$ Department of Public \\ Health, College of Health Science and \\ Medicine, Dilla University, Dilla, Ethiopia
}

Background: This study is therefore designed to assess dietary practices and its determinant among pregnant women in Gedeo zone, southern Ethiopia, 2018.

Methods: A community-based cross-sectional study was employed at Gedeo zone, southern Ethiopia from May to June 2018 among 351 study participants. The sample size was calculated using a single population proportion formula. Pregnant women were identified by health extension workers. A lottery method was used to select each pregnant woman. Sample was drawn proportionally based on the number of pregnant women in each selected kebele (small administrative unit). The dietary practice of pregnant women was determined by using ten items. Knowledge of pregnant women about dietary consumption was assessed by using 8 questions. Attitude towards dietary practice was assessed by asking 9 attitude questions. Data were entered into EpiData 3.1 and cleaned and analyzed by using the statistical package for social science (SPSS) version 24. Binary logistic regression analysis was employed to identify factors associated with dietary practices.

Results: In this study, $113(32.2 \%)$ of study participants had good dietary practices. The mean (standard deviation) age of study participants was $29 \pm 5.9$ years. Over one-third $(76.9 \%)$ of mothers were housewives. Regarding knowledge and attitude, $45.6 \%$ and $42.8 \%$ of respondents had good dietary knowledge and a positive attitude, respectively. Educational status (adjusted odds ratio 2.72; 95\% CI; 1.46-5.07), monthly income (AOR; 3.01, 95\% CI; 1.19-7.63), antenatal follow-up (AOR; 0.46, 95\% CI; 0.23-0.94), knowledge (AOR; 2.32 , 95\% CI; 1.23-4.37) and attitude (AOR; $1.9,95 \% \mathrm{C} ; 1.03-3.52$ ) were determinants of dietary practices.

Conclusion: Less than one-third of pregnant women $(32.2 \%)$ presented good dietary practices. Educational status of the mother, monthly income, ANC visit, knowledge, and attitude were the factors that affect the dietary practices of pregnant women. Since dietary practices of pregnant women are relatively low in the current study, community-based nutrition education specifically on intake of both micro- and macronutrients during pregnancy should be considered by the federal and regional governments of Ethiopia.

Keywords: dietary practices, pregnant women, Dilla Zuria, southern Ethiopia

\section{Introduction}

A balanced diet means taking adequate types of foods and beverages in terms of both variety and quantity to provide adequate nutrition and calorie for building body cells, tissues, and organs. ${ }^{1}$ Nutrition during pregnancy should schedule to
Correspondence: Mahlet Birhane Department of Nutrition, College of Medicine and Health Science, Dilla

University, Dilla, Ethiopia

Tel +25I 912294306

Email mahletbir2007@gmail.com
Nutrition and Dietary Supplements 2020:12 267-275 
provide adequate energy and nutrients for the mother as well as for the inborn infants. ${ }^{2}$

During pregnancy, all mothers need more and diversified foods and micronutrient supplements. The energy requirement rises in the second and third trimesters. Especially, in the third trimester of pregnancy, women require more protein, carbohydrate and fats to meet the increased energy requirements. ${ }^{3}$ During this crucial period, a wise selection of fats plays an important role for the fetal development and infant growth. Increase intakes of healthy fatty acid (polyunsaturated fats) rather than to increase the intake of total fats: an adequate intake of docosahexaenoic acid (DHA, of then-3 series) is essential for the growth and development of brain and retina. ${ }^{4}$ Inadequate intakes of macro- and micro-nutrients during pregnancy have several consequences and complications like maternal complications and death, fetal and newborn death, birth defects, and decreased physical and mental potential of the child in fetal growth restriction and adverse prenatal outcomes. ${ }^{5}$

Inadequate intake of nutritious food during pregnancy can affect a woman's life, the newborn infant, the family, and the community at large. ${ }^{6}$ Women who developed iron deficiency anemia before or during pregnancy were at increased risk of delivering preterm, hypoxia, oxidative stress, infection, low birth weight, and also increase the risk of maternal and infant mortality. ${ }^{7}$

Nutrition during pregnancy is a significant public health concern because pregnancy is a critical period during which good maternal nutrition is an important factor that affects the health of both the mother and the child. In 2013, 289,000 women died during and following pregnancy and childbirth. Almost all of these deaths occurred in low-resource settings, and almost all maternal deaths (99\%) occur in developing countries. ${ }^{8}$ A serious problem of maternal undernutrition is reported in most countries in sub-Saharan Africa, South-central and Southeastern Asia, and in Yemen, where more than $20 \%$ of women are malnourished. ${ }^{9}$

In Ethiopia, nutritional problems are among the leading causes of diseases and death. The major problems are macronutrient malnutrition and micronutrient deficiencies such as vitamin A, iron, and iodine. Chronic malnutrition $\left(\mathrm{BMI}<18.5 \mathrm{~kg} / \mathrm{m}^{2}\right)$ among women is a serious problem in Ethiopia which accounts $26 \%$ of malnutrition as is stunting $(13 \%<150 \mathrm{~cm}$ in height $) .{ }^{10}$

The dietary practice is defined as a participant's preference in food consumption or behaviors of dietary habits and can be classified as good dietary practices and poor dietary practices. ${ }^{11}$ Dietary habits, food taboos, and misconceptions are the main factors that affect dietary intake during pregnancy in rural Ethiopia. ${ }^{12}$ In Ethiopia, about $37 \%$ of urban and $34 \%$ of rural mothers reported having micronutrient supplementation for at least three months during their pregnancy. ${ }^{13}$

Even though researches focused on maternal health is common, research related to dietary practice and other nutrition is limited at large in Ethiopia in general and in Dilla zuria woreda in particular. In addition, identifying factors that affect the dietary practices of pregnant women is important to initiate timely and appropriate interventions. So, this study was intended to determine dietary practices and its determinant factors among pregnant women at Dilla zuria woreda, Gedeo zone, SNNPR Ethiopia.

\section{Materials and Methods}

This community-based cross-sectional study was employed at Gedeo zone Dilla zuria woreda, SNNPR, Ethiopia from Mayto June, 2018. Dilla zuria woreda is $4 \mathrm{~km}$ from Dilla town (center of Gedeo zone), $81 \mathrm{~km}$ from Hawassa (center of SNNPR), and $370 \mathrm{~km}$ from Addis Ababa (the center of Ethiopia). Based on the woreda administration office 2017, the total population of the woreda is 127,022 (Male $=49.8 \%$ and Female $=$ $50.2 \%)$. The average total pregnant women in the woreda is 4404 . The climate is woinadega. The woreda has a total area of 370 hectares $\left(3.7 \mathrm{~km}^{2}\right)$. It has 5 health centers, 27 health posts, and 5 drug stores. All pregnant women residing at Dilla zuria woreda were the source population while pregnant mothers who resided in the selected kebele of Dilla zuria woreda were the study population. All pregnant women who permanently resided in the study area were included for this study while pregnant women who were severely sick and or not stable to respond to question were excluded.

The sample size (n) required for this survey was determined by Epi Info version 7 by using a single population proportion formula $(\mathrm{n}=(\mathrm{Z} \alpha / 2) 2 \mathrm{p} \mathrm{q} / \mathrm{d} 2)$ by assuming an expected prevalence of $33.9 \%{ }^{14}$ Margin of error $5 \%$ and 95\% CI. Since the average total pregnant mother in Dilla zuria woreda 4404 is below 10,000 , reduction formula was employed as follows $\mathrm{nf}=\mathrm{ni} / 1+\mathrm{ni} / \mathrm{N} \mathrm{nf}=344 / 1+(344 / 4404)$ $=319$. By adding $10 \%$ for none response, the final calculated sample size becomes 351 .

For the second-specific objective, the sample size was calculated by using an open Epi Info version7 based on 
Table I Sample Size Determination for the Associated Factor of the Dietary Practice of Pregnant Mother

\begin{tabular}{|l|l|l|l|l|l|}
\hline $\begin{array}{l}\text { Significant } \\
\text { Variables }\end{array}$ & Cl & Power & $\begin{array}{l}\text { Exposed to } \\
\text { Unexposed }\end{array}$ & AOR & $\begin{array}{l}\text { Sample } \\
\text { Size }\end{array}$ \\
\hline $\begin{array}{l}\text { Monthly } \\
\text { income } \\
\text { Information } \\
\text { about } \\
\text { nutrition } \\
\begin{array}{l}\text { Mothers } \\
\text { education }\end{array}\end{array}$ & $95 \%$ & $80 \%$ & 11.0 & 5.9 & 146 \\
\hline
\end{tabular}

minimum detectable OR, $5 \%$ level of significance, and power $80 \%, 95 \%$ CI (Table 1).

The largest sample size is the one which is calculated for the first specific objective which is 319 and adding a $10 \%$ non-response rate it becomes 351 .

\section{Sampling Procedure}

According to statistical rule of thumb, from the total 17 kebele of Dilla zuria woreda 30\% (five kebeles) were selected by using the lottery method. The sampling frame was prepared based on the family folder from the kebele's Health extension workers (HEWs). Then, the sample size was allocated proportionally to each kebele based on the number of pregnant women in each kebele. Then, a simple random sampling technique was implemented to select the households with eligible study sample until the sample size is attended. The selected study subject who refused to participate in the study was considered as non-respondent.

\section{Tools and Procedures}

To collect the data, structured and semi-structured interviews administer questionnaires were used. The data were collected by using six trained diploma teachers. The questionnaires have six contents. Namely, demographic characteristics, financial factors, obstetric factors, diet-related knowledge, attitude, and practices. Knowledge of pregnant women about dietary consumption was assessed by using 8 questions that were used to assess knowledge of pregnant women regarding dietary recommendation during pregnancy. A knowledge score was calculated for each participant based on the number of questions that were correctly answered in the knowledge assessing questions section. Each correct response was scored 1 and incorrect response scored 0 . The mean value was used to categorize respondents as having good knowledge or poor knowledge. A pregnant mother was considered to have good knowledge if she correctly answered above the mean score of knowledge assessing questions and poor knowledge if she answered equal and below the mean score of knowledge assessing questions. The questionnaire was taken from previously validated questionnaire. ${ }^{15}$ Attitude towards dietary practice was assessed by asking 9 attitude questions (Table S1). When the pregnant women agreed for questions regarding attitude, she has a score of 3 points, for neutral a score of 2 points and if she answers disagree, scored 1 point following the Likert scale. Then, the aggregate attitude score was determined for each pregnant woman by summing up the scores across the nine attitudes related questions. A pregnant woman was considered to have a positive attitude if she had scored more than the mean score out of the nine items. If she had scored below or equal to the mean point, she was considered as having a negative attitude. ${ }^{16,17}$ The dietary practice of pregnant mothers was determined by using ten items (Table S2). For each dietary practice question, one point was given if the respondents answer correctly and zeropoint if she answered incorrectly. The aggregate dietary practice score was determined by summing up the scores for each respondent's answers for all ten dietary practice items. Pregnant women were considered to have poor dietary practice if they scores below the mean dietary practice assessing questions and good dietary practices if they scores above and equal to the mean. ${ }^{18}$

\section{Quality Control and Analysis}

Data collection tools for this study were first prepared in English, translated to the local language, and re-translated back to English to prove its consistency. All data collectors and supervisors were informed about the tools and the participants. Before the actual data collection period, a pre-test on $5 \%$ of the sample was conducted and modification was done accordingly. Data were monitored and checked for completeness on daily basis during data collection. The supervisors have checked the data at each data collection day. Data were entered into EpiData version 3.1 and analysis was done by using the Statistical Package for Social Sciences (SPSS) version 20. Descriptive statistics were displayed by using frequency, percentage, mean and standard deviation. Binary logistic regression analysis was done to show the association between dependent and independent predictors. Variables with P-value of $<0.25$ in the univariate analysis was candidate for multivariate analysis. Finally, the degree of association was declared by using 
AOR with 95\% CI. Multicollinearity was ruled out through co-linearity diagnostic check. According to the known cutoff point, there was no Multicollinearity between independent variables. Model fitness to the dependent variable with the predictors was checked by hosmer and lemeshow test for goodness of fit.

\section{Results}

\section{Socio-Demographic and Economic Factors of Respondents}

In the current study, 351 pregnant women were included with a response rate of $100 \%$. The mean (standard deviation) age of study participants was 29 \pm 5.9 years. Most $(96.6 \%)$ of study participants were married. About, 270 (76.9\%) of mothers were housewives; whereas only $8.3 \%$ were government employees. Below half (48.7\%) of the husbands were a farmer whereas $20.5 \%$ where government employees. Most of the respondents 260 (74.1\%) had family size $\geq 5$. Regarding educational status, about half $(50.4 \%)$ of study participants had no formal education while $11.4 \%$ had secondary and above level. Above half $(53.8 \%)$ of husbands had primary education. Among the respondents, 192 (54.7\%) of mothers had a monthly income of below 28.5dollars whereas 46 (13.1\%) had a monthly income of above 57dollars. From 351 study participants, a hundred fifty $(42.7 \%)$ had $\geq 5$ live births, while two-third $(67 \%)$ of them had $<2$ years of an interval between the last two pregnancies. The majority (73.1\%) of the study participants had an ANC visit during their pregnancy (Table 2).

\section{Dietary Knowledge of Respondents}

In this study, 160 (45.6\%) of respondents had good knowledge of the dietary practice. Over half 191 (54.4\%) of the respondents did not know about a balanced diet. Regarding the source of carbohydrate, 260 (74.1\%) of the respondent did not respond to the proper source. The mean $( \pm \mathrm{SD})$ knowledge score of respondents was (4.1 \pm 2.9$)$.

\section{Attitude Towards the Dietary Practice}

Below half, (42.8\%) of respondents have scored a positive attitude while 201 (57.2\%) scored a negative attitude for dietary practice during pregnancy. The mean $( \pm \mathrm{SD})$ attitude score of the study participants was (20.0 \pm 2.93$)$ out of 27 possible points. About 151 (43\%) of the study participants had disagreed for eating an additional meal. Below
Table 2 Socio-Demographic Characteristics of Pregnant Mothers in Dilla Zuria Woreda, Southern Ethiopia, 2018

\begin{tabular}{|c|c|c|}
\hline Variables $(n=35 I)$ & Frequency & Percentage \\
\hline \multicolumn{3}{|l|}{ Age } \\
\hline $15-24$ & 112 & 31.9 \\
\hline $25-34$ & 175 & 49.9 \\
\hline $35-49$ & 64 & 18.3 \\
\hline \multicolumn{3}{|l|}{ Marital status } \\
\hline Married & 339 & 96.6 \\
\hline Separated & 12 & 3.4 \\
\hline \multicolumn{3}{|l|}{ Family size } \\
\hline$<2$ & 3 & 0.9 \\
\hline $3-4$ & 88 & 25.1 \\
\hline$>5$ & 260 & 74.1 \\
\hline \multicolumn{3}{|l|}{ Pregnant mother educational level } \\
\hline No formal education & 177 & 50.4 \\
\hline Primary education & 134 & 38.1 \\
\hline Secondary and above & 40 & $1 \mathrm{I} .4$ \\
\hline \multicolumn{3}{|l|}{ Husband educational level } \\
\hline No formal education & 73 & 20.8 \\
\hline Primary education & 189 & 53.8 \\
\hline Secondary and above & 89 & 25.4 \\
\hline \multicolumn{3}{|l|}{ Husband occupation } \\
\hline Farmer & $17 \mid$ & 48.7 \\
\hline Private business & 108 & 30.8 \\
\hline Government Employee & 72 & 20.5 \\
\hline \multicolumn{3}{|l|}{ Monthly income } \\
\hline$<1000$ & 192 & 54.7 \\
\hline $1000-2000$ & 113 & 32.2 \\
\hline$>2000$ & 46 & 13.1 \\
\hline \multicolumn{3}{|l|}{ Occupational status of mothers } \\
\hline Housewife & 270 & 76.9 \\
\hline Private business & 52 & 14.8 \\
\hline Government employee & 29 & 8.3 \\
\hline \multicolumn{3}{|l|}{ Total number of pregnancy } \\
\hline$\leq 2$ & 65 & 18.5 \\
\hline $3-4$ & 117 & 33.3 \\
\hline$\geq 5$ & 169 & 48.1 \\
\hline \multicolumn{3}{|l|}{ Total number of live birth } \\
\hline$\leq 2$ & 97 & 27.6 \\
\hline $3-4$ & 59 & 16.8 \\
\hline$\geq 5$ & 150 & 42.7 \\
\hline \multicolumn{3}{|l|}{ Last two pregnancy interval(in year) } \\
\hline$<2$ & 234 & 66.7 \\
\hline $2-5$ & 45 & 12.8 \\
\hline$\geq 5$ & 24 & 6.8 \\
\hline \multicolumn{3}{|l|}{ Antenatal visit } \\
\hline Did not have ANC visit & 94 & 26.7 \\
\hline Have ANC visit & 257 & 73.3 \\
\hline
\end{tabular}


half $(45.9 \%)$ of the respondents had agreed to prepare meals with iodized salt (Table 3).

\section{The Dietary Practice of Study Participants}

Out of 351 respondents, 113 (32.2\%) had good dietary practices, $238(67.8 \%)$ of them ate once or twice daily

Table 3 Attitude of Pregnant Mothers Towards Dietary Practice in Dilla Zuria Woreda, Southern Ethiopia, $2018(n=351)$

\begin{tabular}{|c|c|c|}
\hline \multicolumn{3}{|l|}{ Attitude of Mother Frequency Percent (\%) } \\
\hline Eat additional frequency of food per day? & & \\
\hline Disagree & $|5|$ & 43 \\
\hline Neutral & 97 & 27.6 \\
\hline Agree & 103 & 29.3 \\
\hline Eat more carbohydrates? & & \\
\hline Disagree & 73 & 20.8 \\
\hline Neutral & 148 & 42.2 \\
\hline Agree & 130 & 37.2 \\
\hline $\begin{array}{l}\text { Eat more proteins source food such as beans, } \\
\text { egg, nut ...? }\end{array}$ & & \\
\hline Disagree & 60 & 17.1 \\
\hline Neutral & 137 & 39 \\
\hline Agree & 154 & 43.9 \\
\hline $\begin{array}{l}\text { Preparing of more milk and its products during } \\
\text { pregnancy? }\end{array}$ & & \\
\hline Disagree & 69 & 19.7 \\
\hline Neutral & 89 & 25.4 \\
\hline Agree & 193 & 55 \\
\hline Prepare meals with iron-rich foods? & & \\
\hline Disagree & 79 & 22.5 \\
\hline Neutral & 126 & 35.9 \\
\hline Agree & 146 & 41.6 \\
\hline $\begin{array}{l}\text { Like the taste of meat and other iron-rich food } \\
\text { item or meals? }\end{array}$ & & \\
\hline Disagree & 41 & 11.7 \\
\hline Neutral & 169 & 48.1 \\
\hline Agree & 141 & 40.2 \\
\hline Omega 3 rich foods like olive oils, fish ...? & & \\
\hline Disagree & 62 & 17.7 \\
\hline Neutral & 237 & 67.5 \\
\hline Agree & 52 & 14.8 \\
\hline The taste of milk and milk products? & & \\
\hline Disagree & 35 & 10 \\
\hline Neutral & 59 & 16.8 \\
\hline Agree & 257 & 73.2 \\
\hline Prepare meals with iodized salt? & & \\
\hline Disagree & 49 & 14 \\
\hline Neutral & $14 \mid$ & 40.2 \\
\hline Agree & 161 & 45.9 \\
\hline
\end{tabular}

and $90(25.6 \%)$ ate three or four times daily. The majority, $257(73.2 \%)$ consume green leafy vegetables, 56 (16.5\%) consume animal source food on a daily bases. Among the 351 study participants, $122(34.8 \%)$ of them practiced infrequent meals between the main meal patterns, 173 (49.3\%) respondents had followed a specific dietary regimen. Out of the study participants, 274 (78.1\%) had iron/ folic acid supplements during pregnancy. Nearly onefourth of $86(24.4 \%)$ of the respondents had food avoidance practice. For this, $15(4.3 \%)$ reason out culture, 37 (10.5\%) wrongly perceived for some specific food in which it may result in big baby, and $35(10 \%)$ reason out as it may cause difficulty of delivery (Table 4 ).

\section{Factors Associated with Dietary Practices of Pregnant Women}

In the final logistic regression model, a variable like, maternal education, monthly income, ANC visit, knowledge, and attitude have shown significant association with the outcome variable. Respondents with formal education were 2.7 times more odds of good dietary practice than those without formal education (AOR $=2.7,95 \%$ CI $1.45-5.07)$. Study participants with a monthly income of more than 57dollars and between 28.5-57dollars were 3 and 2 times higher chance to have good dietary practice than those with a monthly income of below 28.5dollars (AOR=3.01, 95\% CI, 1.19-7.62) and $(\mathrm{AOR}=2,95 \% \mathrm{CI}, 1.04-3.86)$ respectively.

In this study, mothers who had no ANC follow-up were $54 \%$ less chance of good dietary practice than those mothers with ANC follow-up (AOR $=0.46,95 \% \mathrm{CI}$, 0.23-0.94). Knowledge was another determinant factor for dietary practice. The odds of good dietary practice for those with good knowledge were 2.32 times higher than those with poor knowledge (AOR $=2.31,95 \% \mathrm{CI}, 1.2-4.3$ ). Similarly, the attitude was significantly associated with the outcome variable. Study participants with a positive attitude had 1.9 times higher odds of good dietary practice than participants with a negative attitude $(\mathrm{AOR}=1.9,95 \%$ CI, 1.03-3.52) (Table 5).

\section{Discussion}

Pregnant women should plan to have adequate quality and quantity of food to provide the extra energy and micronutrient requirement for herself as well as for the fetal growth. ${ }^{2}$ Inadequate intake of both macro- and micronutrients during pregnancy has negative maternal and fetal consequences like maternal death, fetal and newborn death, birth defects, and decreased physical and mental 
Table 4 Dietary Practice of Pregnant Mother in Dilla Zuria Woreda, Southern Ethiopia, $2018(n=351)$

\begin{tabular}{|c|c|c|}
\hline The Dietary Practice of & Frequency & $\begin{array}{l}\text { Percent } \\
\text { (\%) }\end{array}$ \\
\hline \multicolumn{3}{|c|}{ Follow specific dietary regimen? } \\
\hline Yes & 173 & 49.3 \\
\hline No & 178 & 50.7 \\
\hline \multicolumn{3}{|c|}{$\begin{array}{l}\text { Eat fresh fruits, such as orange, } \\
\text { lemon, mango? }\end{array}$} \\
\hline Yes & 279 & 79.5 \\
\hline No & 72 & 20.5 \\
\hline \multicolumn{3}{|c|}{$\begin{array}{l}\text { Do you have an iron-folic acid } \\
\text { supplement? }\end{array}$} \\
\hline Yes & 274 & 78.1 \\
\hline No & 77 & 21.9 \\
\hline \multicolumn{3}{|c|}{$\begin{array}{l}\text { Do you have the habits of eating } \\
\text { snacks between meals? }\end{array}$} \\
\hline Yes & 122 & 34.8 \\
\hline No & 229 & 65.2 \\
\hline \multicolumn{3}{|c|}{$\begin{array}{l}\text { The habit of eating carbohydrate } \\
\text { source food? }\end{array}$} \\
\hline Yes & 165 & 47.0 \\
\hline No & 186 & 53.3 \\
\hline \multicolumn{3}{|c|}{$\begin{array}{l}\text { Do you avoid any food or diet in this } \\
\text { pregnancy? }\end{array}$} \\
\hline Yes & 86 & 24.5 \\
\hline No & 265 & 75.5 \\
\hline \multicolumn{3}{|c|}{$\begin{array}{l}\text { Reason for the avoidance of any food } \\
\text { or diet in the current pregnancy }\end{array}$} \\
\hline Culture & 15 & 4.3 \\
\hline Make the baby big & 37 & 10.5 \\
\hline Makes delivery difficult & 35 & 10.0 \\
\hline \multicolumn{3}{|c|}{$\begin{array}{l}\text { Animal source foods like meat, } \\
\text { liver, milk and others within a day? }\end{array}$} \\
\hline Yes & 56 & 16.5 \\
\hline No & 295 & 84 \\
\hline \multicolumn{3}{|l|}{ Meal frequency } \\
\hline $1-2$ & 238 & 67.8 \\
\hline $3-4$ & 90 & 25.6 \\
\hline$>5$ & 23 & 6.6 \\
\hline \multicolumn{3}{|l|}{$\begin{array}{l}\text { Consumption/eating fresh } \\
\text { vegetables daily? }\end{array}$} \\
\hline Yes & 257 & 73.2 \\
\hline No & 94 & 26.8 \\
\hline \multicolumn{3}{|l|}{ Overall dietary practice } \\
\hline Good (score>7.5) & 113 & 32.2 \\
\hline Poor practice(Score $\leq 7.5)$ & 238 & 67.8 \\
\hline
\end{tabular}

potential of the child in fetal growth restriction and adverse prenatal outcomes. ${ }^{5}$ Inadequate intake of foods rich in polyunsaturated fatty acid (PUFAs) has negative consequences on brain and visual development. The transport of DHA to the fetus during pregnancy is highly dependent on maternal dietary intake. ${ }^{4}$ Inadequate intake of these foods during pregnancy has also a negative consequence on milk production. Researches have shown that, a low intake of foods that are natural sources of n-3 fatty acids (vegetable oils, fish, and seafood during pregnancy leads to a significant reduction of DHA levels in erythrocytes and also in breast milk. ${ }^{19}$ So, this study was aimed to assess the dietary practice and its determinant among pregnant mothers in Gedeo zone, southern Ethiopia. This study showed that only $32.2 \%$ of pregnant mothers have good dietary practices. The finding of the current study is in line with a study conducted in Oromia region, Ethiopia which showed that $33.9 \%$ of study participants have reported good dietary practice. ${ }^{14}$

But, this finding was slightly lower than a study done in Gondar Town North West, Ethiopia, Bahir Dar city and Dessie town which found $40.1 \%,{ }^{20} 39.3 \%{ }^{21}$ and $43.2 \%{ }^{22}$ of good dietary practice among pregnant women, respectively. The possible justification for the difference between those study findings is due to the differences in demographic characteristics of the study participants. In our study, participants have resided in rural parts of the community. Urban communities have possibilities to get better access to nutrition information through different mass media. On the contrary, the prevalence of good dietary practice in the current study is higher than a study done in west Gojjam zone northern Ethiopia which revealed that, only $19.9 \%$ of pregnant women had good dietary practices. ${ }^{23}$ This gap in the prevalence of dietary practice might be due to the difference in a geographical location, agro-economic practices, cultural and religion differences of a community and seasonal variation in food production and consumption. On the other hand, agricultural food production varies across different geographical locations of Ethiopia. For example, the staple foods of southern parts of Ethiopia are mostly root and tuber crops, fruits and vegetables while northern parts of Ethiopia produce and depend on cereal crops. Ethiopia is also a habitat of diverse religion followers.

Even though the health sectors of Ethiopia developed different health and nutrition programs especially for those 
Table 5 Binary and Multiple Logistic Regression Analysis for Factors Associated with the Dietary Practice Among Pregnant Mothers in Dilla Zuria Woreda, Gedeo Zone, South Ethiopia, $2018(n=35 I)$

\begin{tabular}{|c|c|c|c|c|c|}
\hline \multirow[t]{2}{*}{ Variables } & \multirow[t]{2}{*}{ Category } & \multicolumn{2}{|c|}{ Dietary Practice Mothers } & \multirow[t]{2}{*}{ COR(95\% Cl) } & \multirow[t]{2}{*}{ AOR(95\% Cl) } \\
\hline & & Good & Poor & & \\
\hline Educational status of the mother & $\begin{array}{l}\text { Not formal education } \\
\text { Formal Education }\end{array}$ & $\begin{array}{l}28(\mid 15.8 \%) \\
85(48.9 \%)\end{array}$ & $\begin{array}{l}149(84.2 \%) \\
89(51.1 \%)\end{array}$ & $\begin{array}{l}\text { I } \\
5.08(3.08-8.39)^{*}\end{array}$ & $\begin{array}{l}\text { I } \\
2.72(1.46-5.07)^{* *}\end{array}$ \\
\hline Educational status of the husband & $\begin{array}{l}\text { Formal Education } \\
\text { Not formal education }\end{array}$ & $\begin{array}{l}61(83.6 \%) \\
177(63.7 \%)\end{array}$ & $\begin{array}{l}12(16.4 \%) \\
101(36.3 \%)\end{array}$ & $\begin{array}{l}\text { I } \\
0.345(0.18-0.67)^{*}\end{array}$ & $\begin{array}{l}\text { I } \\
0.629(0.26-\mid .53)\end{array}$ \\
\hline Occupational status of husband & $\begin{array}{l}\text { Farmer } \\
\text { Private business } \\
\text { Government employee }\end{array}$ & $\begin{array}{l}|4|(82.5 \%) \\
63(58.3 \%) \\
34(47.2 \%)\end{array}$ & $\begin{array}{l}30(17.5) \\
45(41.7 \%) \\
38(52.8 \%)\end{array}$ & $\begin{array}{l}\text { I } \\
3.35(1.94-5.8 I)^{*} \\
5.25(2.86-9.65)^{*}\end{array}$ & $\begin{array}{l}\text { I } \\
1.7(0.84-3.47) \\
1.39(0.61-3.19)\end{array}$ \\
\hline Monthly income & $\begin{array}{l}<1000 \\
1000-2000 \\
>2000\end{array}$ & $\begin{array}{l}154(80.2 \%) \\
68(60.2 \%) \\
16(34.8 \%)\end{array}$ & $\begin{array}{l}38(19.8 \%) \\
45(39.8 \%) \\
30(65.2 \%)\end{array}$ & $\begin{array}{l}\text { I } \\
2.68(1.5-3.05)^{*} \\
7.59(3.76-15.34)^{*}\end{array}$ & $\begin{array}{l}\text { I } \\
2.0(1.04-3.85)^{*} \\
3.0(1.19-7.63)^{*}\end{array}$ \\
\hline No of live birth & $\begin{array}{l}\leq 2 \\
3-5 \\
>5\end{array}$ & $\begin{array}{l}57(58.8 \%) \\
45(76.3 \%) \\
110(76.3 \%)\end{array}$ & $\begin{array}{l}40(41.2 \%) \\
14(23.7 \%) \\
40(23.7 \%)\end{array}$ & $\begin{array}{l}1.93(1.12-3.32)^{*} \\
0.86(0.43-1.72) \\
1\end{array}$ & $\begin{array}{l}\text { I.I }(0.57-2.29) \\
0.55(0.23-1.29) \\
1\end{array}$ \\
\hline Gap of pregnancy in years & $\begin{array}{r}<2 \\
2-5 \\
>5\end{array}$ & $\begin{array}{l}57(58.8 \%) \\
45(76.3 \%) \\
110(73.3 \%)\end{array}$ & $\begin{array}{l}40(41.2 \%) \\
14(23.7 \% \\
40(26.7 \%)\end{array}$ & $\begin{array}{l}\text { I } \\
\text { I.89 (0.97-3.67) } \\
4.73(1.97-\mid 1.36)\end{array}$ & $\begin{array}{l}\text { I } \\
2.28(0.54-3.02) \\
2.58(0.91-7.30)\end{array}$ \\
\hline ANC visit & $\begin{array}{l}\text { Not have ANC } \\
\text { Have ANC visit }\end{array}$ & $\begin{array}{l}19(20.2 \%) \\
94(36.6 \%)\end{array}$ & $\begin{array}{l}75(79.8 \%) \\
163(63.4 \%)\end{array}$ & $\begin{array}{l}0.04(0.01-0.16) \\
1\end{array}$ & $\begin{array}{l}0.46(0.23-0.94)^{*} \\
\text { I }\end{array}$ \\
\hline Nutritional information & $\begin{array}{l}\text { Yes } \\
\text { No }\end{array}$ & $\begin{array}{l}135(57.7 \%) \\
103(88.0 \%)\end{array}$ & $\begin{array}{l}99(42.3 \%) \\
14(12.0 \%)\end{array}$ & $\begin{array}{l}\text { I } \\
0.185(0.10-0.34)\end{array}$ & I. $59(0.6 \mathrm{I}-4.13)$ \\
\hline Knowledge & $\begin{array}{l}\text { Good knowledge } \\
\text { Poor knowledge }\end{array}$ & $\begin{array}{l}157(82.2 \%) \\
81(50.6 \%)\end{array}$ & $\begin{array}{l}34(17.8 \%) \\
79(49.4 \%)\end{array}$ & $\begin{array}{l}4.5(2.78-7.30) \\
\text { I }\end{array}$ & $\begin{array}{l}2.32(1.23-4.37)^{* *} \\
1\end{array}$ \\
\hline Attitude & $\begin{array}{l}\text { Positive } \\
\text { Negative }\end{array}$ & $\begin{array}{l}\text { I56 (79.2\%) } \\
82(53.2 \%)\end{array}$ & $\begin{array}{l}4 I(20.8 \%) \\
72(46.8 \%)\end{array}$ & $\begin{array}{l}3.34 \mathrm{I}(2.09-5.33) \\
\mathrm{I}\end{array}$ & $\begin{array}{l}1.90(1.03-3.52)^{*} \\
1\end{array}$ \\
\hline
\end{tabular}

Notes: ${ }^{* *} \mathrm{p}<0.01 ;{ }^{*} \mathrm{p}<0.05$.

Abbreviations: COR, crude odds ratio; AOR, adjusted odds ratio.

vulnerable population groups, dietary consumption during pregnancy does not show progress and still, it is a possible cause for maternal and child related complications. For example, in our study, pregnant mothers had skipped usual diets, maintaining the expected frequency of feeding during pregnancy is also sub-optimal. Over half $(65.2 \%)$ of the study participants skipped snacks and $67.8 \%$ had sub-optimal meal frequency. This figure was in line with findings from the Oromia region in which $59.9 \%$ and $66.1 \%$ of study participants skipped snacks and had suboptimal meal frequency, respectively. ${ }^{14}$

Regarding educational status, study participants with formal education had 2.7times more odds of practicing good dietary consumption during pregnancy than those who were not formal education. This is similar with findings from southwestern Bangladesh that reported secondary complete level of education had, 3.8 times more odds of having diversified diet than secondary incomplete $^{24}$ and in Gondar town which revealed that diploma and more holder pregnant mother had 2.6times more chance of having adequate dietary consumption. ${ }^{20}$ The possible explanation for this is mothers with better education have more chances to acquire nutrition and other health-related information from different sources like leaflets, magazines, and other media.

This study also revealed monthly income as a significant predictor of good dietary practice. Comparing to pregnant women who earn less than 28.5dollars, mothers with a monthly income of above 57dollars and b/n 28.5-57dollars had three and two times increase the chance to have good dietary practice, respectively. The possible explanation for this is that self-reliance mothers can be afforded for 
different food items and can feed the whole family as well as for her. A similar finding was reported from a study conducted in northwestern Ethiopia Gonder town which reported that respondents who earn b/n 28.5-57 dollars/ month 2 times more odds of having good dietary practice than those $<28.5$ dollars monthly income ${ }^{20}$ and Bahirdar city which revealed that monthly family income $>57$ dollars and b/n 28.5-57dollars were 3.17 and 2.84 times more odds of practicing good diet than those whose monthly income of

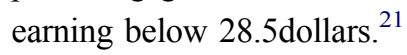

Similarly, knowledge regarding diet during pregnancy has shown a significant association with the participant's dietary practice. Knowledgeable women had a 2.32times higher chance of good dietary practice during pregnancy than not knowledgeable. This figure is similar to findings from researches which was conducted in somewhere in our country. According to this research, pregnant mothers who have knowledge were 3.8times increased chance of good dietary practice. $^{21}$ It is also similar with findings from Bangladesh which shows mothers with medium and high level of knowledge have 18times and 30 times higher consumption of Iron-Folic Acid as compared to low knowledge. $^{25}$

In this study, mothers who had a positive attitude were $90 \%$ more odds of good dietary practice than those mothers with a negative attitude. This finding is similar to the findings of Malaysia which indicated that lower dietary practices of mothers were associated with low attitude towards diet during pregnancy. ${ }^{26}$ This may have explained as when a woman has a positive attitude to diet during pregnancy, she becomes more concerned and can put it in to practice immediately.

As a strength, this study used non-healthcare provider (teachers) data collectors this could enable to have professionally unbiased data whereas a lack of previous similar study to made comparison is mentioned as a limitation.

\section{Conclusion}

In the current study, the prevalence of good dietary practice during pregnancy is only $32.2 \%$ which is below optimal. Educational status of the mother, monthly income, ANC visit, dietary knowledge, and positive attitude to dietary intake during pregnancy was found to be significant predictors of dietary practice. In order to improve dietary practice and alleviate the associated factors, the federal and regional government of Ethiopia, community health extension workers and other responsible stakeholders should focus on pregnant women to have ANC follow-up, increase knowledge and positive perception towards nutrition during pregnancy through community-based nutrition education program and local mass media. In addition, implementations of already existing key nutrition message need to be strengthened. Lastly, since high-income level is positively associated with good dietary practice, involving pregnant women in different sustainable income generating activities should also be considered.

\section{Abbreviations}

ANC, Ante Natal Care; AOR, Adjusted Odds Ratio; BMI, body mass index; CI, Confidence Interval; COR, Crude Odds Ratio; DURH, Dilla University Referral Hospital; ETB, Ethiopian Birr; HEW, Health Extension Worker; SD, standard deviation; SNNPR, Southern Nations Nationalities and People Region; SPSS, Statistical Package for the Social Sciences.

\section{Ethical Consideration}

All procedures undertaken during data collection were in accordance with the ethical review board of Dilla University and the Helsinki Declaration. The study was approved by the ethical review board of Dilla University. Before data collection, the objective of the study was told to the study participants. To keep participants secrete during the data collection period, a unique identification number was used. Consent for participants with age under 18years was taken from their parents/guardians. Finally written and verbal informed consent was given.

\section{Acknowledgments}

We would like to thank Dilla University College of health science and medicine for the unreserved help. Our thanks also go to Dilla Zuria Health Office which supplying the necessary information. Finally, it is a pleasure for us to thank all data collectors, supervisors, and those study participants.

\section{Author Contributions}

All authors contributed to data analysis, drafting or revising the article, have agreed on the journal to which the article will be submitted, gave final approval of the version to be published, and agree to be accountable for all aspects of the work.

\section{Disclosure}

The authors report no conflicts of interest for this work. 


\section{References}

1. Shekar M, Heaver R, Lee Y-K. Repositioning Nutrition as Central to Development: A Strategy for Large Scale Action. World Bank Publications; 2006.

2. Mora JO, Nestel PS. Improving prenatal nutrition in developing countries: strategies, prospects, and challenges. Am J Clin Nutr. 2000;71(5):1353S-63S. doi:10.1093/ajen/71.5.1353s

3. Brown LS. Nutrition Requirements During Pregnancy. Essentials of Life Cycle Nutrition United States of America. Jones and Bartlett Publishers; 2011.

4. Marangoni F, Cetin I, Verduci E, et al. Maternal diet and nutrient requirements in pregnancy and breastfeeding. An Italian consensus document. Nutrients. 2016;8(10):629. doi:10.3390/nu8100629

5. Thompson JM, Wall C, Becroft DM, Robinson E, Wild CJ, Mitchell EA. Maternal dietary patterns in pregnancy and the association with small-for-gestational-age infants. Br J Nutr. 2010;103 (11):1665-1673. doi:10.1017/S0007114509993606

6. Adikari A, Sivakanesan R, Wijesinghe D, Liyanage C. Assessment of nutritional status of pregnant women in a rural area in Sri Lanka. 2016.

7. Kemunto ML. Dietary diversity and nutritional status of pregnant women aged 15-49 years attending Kapenguria District Hospital West Pokot County. Kenya kenayatta University Institutional Repository. 2013.

8. Ronsman C, Graham WJ; Lancet Maternal Survival Series steering group. Maternal mortality: who, when, where and why. Lancet. 2006;368(9542):1189-1200.

9. Black RE, Allen LH, Bhutta ZA, et al. Maternal and child undernutrition: global and regional exposures and health consequences. Lancet. 2008;371(9608):243-260. doi:10.1016/S0140-6736(07)61690-0

10. Dagne E. Role of socio-demographic factors on utilization of maternal health care services in Ethiopia: Umeå International School of Public Health; 2010.

11. Worku A, Abebe SM, Wassie MM. Dietary practice and associated factors among type 2 diabetic patients: a cross sectional hospital based study, Addis Ababa, Ethiopia. SpringerPlus. 2015;4(1):15. doi:10.1186/s40064-015-0785-1

12. Holden J. Nutrition Causal Analysis Maize Livelihood Belt of Aleta Chucko and Aleta Wondo Woredas. Sidama Zone: SNNPR Ethiopia Final Report; 2014.

13. Agency CS. Ethiopia mini demographic and health survey 2014. Addis Ababa: CSA; 2014.

14. Daba G, Beyene F, Garoma W, Fekadu H. Assessment of nutritional practices of pregnant mothers on maternal nutrition and associated factors in Guto Gida Woreda, east Wollega zone, Ethiopia. Sci Technol Arts Res J. 2013;2(3):105-113. doi:10.4314/star.v2i3.98748
15. Nivedita K, Fatima S. Knowledge, attitude and practices of pregnant women regarding anemia, iron rich diet and iron supplements and its impact on their hemoglobin levels. Int J Reprod Contracept Obstet Gynecol. 2016;5(2):425-431.

16. Tenaw Z, Arega M, Tachbele E. Nutritional knowledge, attitude and practices among pregnant women who attend antenatal care at public hospitals of Addis Ababa, Ethiopia. Int J Nurs Midwifery. 2018;10 (7):81-89. doi:10.5897/IJNM2017.0289

17. Macнаs Y. Guidelines for Assessing Nutrition-Related Knowledge, Attitudes and Practices Manual. Food and Agriculture Organization of the United Nations: Food and Agriculture Organization of the United Nations Rome; 2014:1-188.

18. Fouda LM, Ahmed MH, Shehab NS. Nutritional awareness of women during pregnancy. J Am Sci. 2012;8(7):494-502.

19. Barrera C, Valenzuela R, Chamorro R, et al. The impact of maternal diet during pregnancy and lactation on the fatty acid composition of erythrocytes and breast milk of Chilean women. Nutrients. 2018;10 (7):839. doi:10.3390/nu10070839

20. Alemayehu MS, Tesema EM. Dietary practice and associated factors among pregnant women in Gondar town north west, Ethiopia, 2014. Int $J$ Nutr Food Sci. 2015;4(6):707-712. doi:10.11648/j.ijnfs.2015 0406.27

21. Nana A, Zema T. Dietary practices and associated factors during pregnancy in northwestern Ethiopia. BMC Pregnancy Childbirth. 2018;18(1):183. doi:10.1186/s12884-018-1822-1

22. Diddana TZ. Factors associated with dietary practice and nutritional status of pregnant women in Dessie town, northeastern Ethiopia: a community-based cross-sectional study. BMC Pregnancy Childbirth. 2019;19(1):517. doi:10.1186/s12884-019-2649-0

23. Demilew YM, Alene GD, Belachew T. Dietary practices and associated factors among pregnant women in West Gojjam Zone, Northwest Ethiopia. BMC Pregnancy Childbirth. 2020;20(1):18. doi:10.1186/s12884-019-2702-z

24. Shamim AA, Mashreky SR, Ferdous T, et al. Pregnant women diet quality and its sociodemographic determinants in southwestern Bangladesh. Food Nutr Bull. 2016;37(1):14-26. doi:10.1177/03795 72116632137

25. Nguyen PH, Sanghvi T, Kim SS, et al. Factors influencing maternal nutrition practices in a large scale maternal, newborn and child health program in Bangladesh. PLoS One. 2017;12(7):e0179873. doi:10.13 71/journal.pone. 0179873

26. Eni-Olorunda T, Akinbode OO, Akinbode AO. Knowledge and attitude of mothers on risk factors influencing pregnancy outcomes in Abeokuta South Local Government Area, Ogun State. Eur Sci J. 2015;11(11)
Nutrition and Dietary Supplements

\section{Publish your work in this journal}

Nutrition and Dietary Supplements is an international, peerreviewed, open access journal focusing on research into nutritional requirements in health and disease, impact on metabolism and the identification and optimal use of dietary strategies and supplements necessary for normal growth and development. The journal welcomes submitted papers covering original research, basic science, clinical \& epidemiological studies, reviews and evaluations, guidelines, expert opinion and commentary, case reports and extended reports. The manuscript management system is completely online and includes a very quick and fair peer-review system, which is all easy to use. Visit http://www.dovepress.com/testimonials.php to read real quotes from published authors. 